\title{
BETWEEN HELLENISM AND ARABICIZATION. ON THE FORMATION OF AN ETHNOLINGUISTIC IDENTITY OF THE MELKITE COMMUNITIES IN THE HEART OF MUSLIM RULE
}

\author{
ENTRE HELENISMO Y ARABIZACIÓN. \\ SOBRE LA FORMACIÓN DE UNA IDENTIDAD \\ ETNOLINGÜÍSTICA DE LAS COMUNIDADES \\ MELKITAS EN EL SENO DEL PODER ISLÁMICO
}

\author{
Juan Pedro Monferrer-Sala \\ University of Cordova, Spain
}

The present paper deals with the Melkite community as a specific group with an ecclesiastical identity which arose in the Islamic period, in the heartland of Islam, and therefore not in Constantinople. Our aim is to describe those features of this community that arose from the Byzantine Orthodox faith, although formed from anti-Monothelite Syrian Chalcedonian groups, as distinct from the Jacobites, later identified with the Christians of the Umayyad Caliphate who accepted the teachings of the Sixth Ecumenical Council of the Royal Byzantine Church in 681. In this context the label Melkite should not be understood as a synonym of «Greek Orthodox»" but rather of «Chalcedonian», which, for the Syrian Christians, identifies those who followed the Dyothelite dogma.

Key words: Melkites; Umayyads; Chalcedonians; Arabic; Arabicization.
El presente artículo se ocupa de la comunidad melkita, en tanto que grupo que se conformó como una identidad eclesiástica surgida en el periodo islámico, en el corazón del Islam y por tanto no en Constantinopla. De ahí que insistamos en que aquellos rasgos de identidad de esta comunidad que vienen dados por la fe de la Ortodoxia bizantina, formada a partir de grupos de calcedonianos siriacos anti-monotelitas como grupo diferenciado de los jacobitas, que serán identificados posteriormente con los cristianos del califato omeya que aceptaron las enseñanzas del sexto concilio ecuménico de la iglesia imperial bizantina en el año 681. En este contexto, el uso de la denominación melkita no ha de entenderse como sinónimo de «ortodoxos griegos», sino de «calcedonianos», que en el caso de los cristianos siriacos identifica a aquellos que siguieron el dogma diotelita.

Palabras clave: melkitas; omeyas; calcedonianos; árabe; arabización. 


\section{Introduction}

The seventh century gave a remarkable new shape to the Near East, tracing human landscapes that in many respects -despite all the subsequent changes wrought by the passage of time- are still in evidence today. The crisis prompted by the upheaval of the seventh century brought to an end the long-standing status quo, heralding a radical reshaping of all those lands whose geostrategic importance was -and indeed remains- crucial. The emergence of what Wellhausen called Das arabische Reich ${ }^{1}$ was to chart a new human map using new sociopolitical and religious coordinates that arrived with Islam, and were duly described by the chroniclers, each with his own peculiar slant. ${ }^{2}$ A further consideration was that much of the vast territory occupied by Arab contingents as well as Syriac-speaking, Coptic-speaking, Armenian-speaking, Georgian-speaking, and Greekspeaking Christians, was also peopled by Arabic-speaking Christians.

Arabic and Greek belong to different language families, and are therefore not genetically related. Yet from the seventh century onwards, amongst the Melkite authors, the two languages became indispensable elements, inextricably bound together by the Chalcedonian faith. Both languages served as vehicles for oral, cultural and religious communication, and their joint use at times gave rise - particularly in the case of texts produced in Arabic - to fascinating examples of linguistic hybridism that may be seen as a kind of presociolect, given the mutual dependence of the two languages through the translation of Greek texts into Arabic. ${ }^{3}$

With the conquest of the Near East by Arab Muslim troops in the seventh century (630s-640s), the Arabic language gradually supplanted both Aramaic - until then the lingua franca of this whole vast area- and Greek, little by little becoming the spoken and written language in all the territories occupied by Muslims as well as by Christians and Jews. Aramaic had hitherto been the language most widely spoken by Christian groups in inland rural areas, whilst Greek was the preferred language of the coastal settlements. In the seventh century, Jews and Christians in urban areas of Palestine, Syria and

${ }^{1}$ Wellhausen, Das arabische Reich und seine Sturz.

2 Howard-Johnston, Witnesses to a World Crisis.

${ }^{3}$ On 'languages in contact', see Thomason, Language contact. 
Mesopotamia adopted Arabic as the language of communication, prompting a progressive decline in the use of Greek. By the tenth century CE, Arabic had become the language of oral and literary expression for most Jewish and Christian groups, although in certain areas -such as Antioch- large Greek-speaking Christian communities were to be found well into the twelfth century.

In taking over as the official language of the Arab-Islamic state, Arabic gradually replaced the other languages previously used in the new Islamic territories. Obviously, this did not happen overnight, nor was it a process of total replacement; rather, it was the result of a slow but gradual transition from which a new linguistic situation emerged. The mechanism -introduced by caliph 'Abd al-Malik (65-86/685-705) and continued in the reign of his son al-Walìd I (86-96/705-715)consisted in making Arabic the only administrative language, and forbidding the use of Greek. ${ }^{4}$ This decision was not without its problems, not only because the mother tongue of most subjects was a language other than Arabic, but also because even the Arabic-speaking population spoke only dialectal Arabic, as witnessed by the fact that the Umayyad governor of Iraq, al-Hajjāj, had to replace the Arabic used in the chancellery by the appropriate Iraqi dialect. ${ }^{5}$

In Egypt, where there was a sizeable Melkite community, the population essentially spoke two languages until the country was conquered in the mid-seventh century: Greek and Coptic. Greek was also the language of administration, whilst Coptic -often together with Greek- was the language of religion. After the occupation, the use of Greek began to decline; it was ousted by Coptic, which was even used in official documents aimed at local native representatives, thanks to the oral or written mediation of Arabic-speaking Copt translators. ${ }^{6}$ From the ninth century onwards, however, the situation was reversed: Coptic was gradually restricted to religious uses. By the tenth century, members of the Christian intellectual elite systematically wrote in Arabic. ${ }^{7}$

${ }^{4}$ Michael the Syrian, Chronique, vol. II, p. 481. Cf. Vasiliev, "Kitab al-'Unvan", vol. V, p. 498. Cf. Bowersock, Mosaics as History, p. 66.

${ }^{5}$ Hitti, History of Syria, vol. II, p. 473.

${ }^{6}$ Versteegh, The Arabic Language, p. 95.

7 Griffith, "Apologetics and Historiography", pp. 69-70. On the Arabicization of the Christian Egyptians, see Swanson, The Coptic Papacy in Islamic Egypt, pp. 59-81, cf. 43-57. 
A similar situation occurred in Palestine. Since most senior civil servants and scribes in the Umayyad administration were Greekspeaking, or Greek-educated, Greek continued to be the language of administration until the census $\left(t a^{\prime} d \bar{l} l\right)$ and the reforms carried out by caliph 'Abd al-Malik between 697 and 699. ${ }^{8}$ Many of these administrative staff must have been Melkites (rüm), but other groups (e.g. the Monophysities of the Banū Gassān) also contributed to "the prevailing high culture" of the Greek-speaking population, ${ }^{9}$ that had been trained in the techniques of the old East Roman bureaucracy. This Christian administrative corps maintained the procedures of the earlier Byzantine administration until the reforms were introduced. ${ }^{10}$ In Egypt, for example, both Melkites and Monophysites enjoyed the privilege of working in the Islamic state administration. ${ }^{11}$

The 'high culture' referred to by Gutas should not be understood as an exclusively Christian culture - any more than it was among Syriac authors - but rather as a Christian culture that embraced a number of Hellenistic elements essential for reshaping the cultural outlook of the Eastern churches in a pagan setting. ${ }^{12}$ That outlook is closely linked to the work of Christian translators under the patronage of the Abbasid State, in which Melkite translators played a major role, ${ }^{13}$ to the extent of acting as veritable informateurs, providing enlightened Muslim circles with information on the doctrines of the Eastern churches. ${ }^{14}$ But the vast, crucial work of the translators should not be allowed to blind us to the contemporary linguistic situation; the rise of the Abbasids to power prompted a new social situation characterized by the further decline of the Greek language in the Syro-Palestinian milieu, where Arabic even replaced Greek in liturgical rites. ${ }^{15}$

${ }^{8}$ Harrak (transl.), The Chronicle of Zuqnīn, pp. 147-148.

9 Gutas, Greek Thought, Arabic Culture, pp. 17-18.

${ }^{10}$ Fowden and Fowden, Studies on Hellenism, pp. 118-119. Cf. Fowden, Qușayr 'Amra, pp. 269-270.

11 Wilfong, "The non-Muslim communities", p. 186.

12 Wallace-Hadrill, Christian Antioch, pp. 96-116.

${ }^{13}$ Gutas, Greek Thought, Arabic Culture, p. 136.

${ }^{14}$ Kraemer, Humanism in the Renaissance of Islam, pp. 132-134.

${ }^{15}$ Griffith, "Eutychius of Alexandria", p. 161. 


\section{The emergence of a new Christian community in the heart of Islam}

Contrary to expectation, the various Christian communities living in the Islamic state did not all find themselves in the same circumstances; the situation of each community was shaped by its specific historical, religious and sociological context. In sociological terms, for example, the Melkites emerged as an ecclesiastical group during the Islamic period at the very heart of Islam rather than -as has sometimes been suggested-in Constantinople in an exclusively Greek milieu which was later exported to Islamic territories. ${ }^{16}$ Their distinctive features, therefore, are defined by faith in Byzantine orthodoxy subjected to the figure of the Byzantine monarch, ${ }^{17}$ hence the name Mal(a)kiyyūn / Milkiyyūn / Malkā'iyyūn / Malkāniyyūn 'royalist' (<

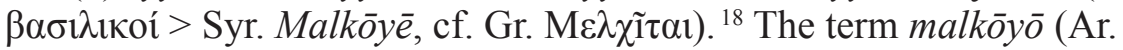
$\operatorname{mal}(a) k \bar{\imath})$ was first used in the mid-fifth century ${ }^{19}$ by Monothelete Syrian Chalcedonians to distinguish themselves from Jacobites, ${ }^{20}$ and was later used to refer to Christians in the Umayyad caliphate who accepted the teachings of the sixth ecumenical council of the Byzantine imperial church in 681, known as Constantinople III. ${ }^{21}$ However, it should be noted that the label 'Melkite' was used not as a synonym of the double epithet 'Greek Orthodox', ${ }^{22}$ but of 'Chalcedonians' (alkhalqidūniyyalal-khalqidüniyyūn), although it was also used to refer specifically to those Syrian Christians who followed the dyothelete dogma. ${ }^{23}$ The term al-rūm (pl. al-arwām) was used to denote Romans

16 Atiya, A History of Eastern Christianity, p. 70. and 83 .

${ }^{17}$ Severus b. al-Muqaffa', Historia patriarcharum alexandrinorum, vol. I, p. 1

${ }^{18}$ Dick, Melkites: Greek Orthodox and Greek Catholics, p. 9. Cf. Graf, Verzeichnis arabischer kirchlicher Termini, p. 108.

19 Al-Khūrī, "al-Malkiyyūn", p. 37.

${ }^{20}$ Harrak (transl.), The Chronicle of Zuqnin, p. 126.

${ }^{21}$ Al-Mas' ${ }^{\top} \bar{d} \bar{i}$, Kitāb al-tanbīh, vol. VIII, p. 153. Cf. Palmer, The Seventh-Century in the West-Syrian Chronicles, pp. 25-26. Griffith, "Melkites', 'Jacobites', and the Christological Controversies", pp. 11-18. See also Nasrallah, "Syriens et Suriens", pp. 493 and 495-496; Fortescue, The Eastern Churches Trilogy. I, p. 14 and 20 and Fortescue, The Eastern Churches Trilogy. II, pp. 184-185.

${ }^{22}$ Cf. Renaudot, Historia Patriarcharum Alexandrinorum Jacobitarum, p. 119. See also Every, "Syrian Christians in Palestine", p. 363 and Atiya, A History of Eastern Christianity, p. 179.

${ }^{23}$ Palmer, The Seventh-Century in the West-Syrian Chronicles, p. 25. 
or Byzantines who professed faith in the Greek Orthodox church of Byzantium, ${ }^{24}$ a feature rarely attributed to the Melkites. By contrast, mal (a)ki / milk $\bar{l}$ was used to refer to Arabic-speaking Christian Chalcedonians living in the territories of Dār al-Isläm, who-together with the Orthodox- remained in communion with Constantinople. ${ }^{25}$

In ethnic or linguistic terms, the distinctive feature of the malkiyyun could be defined as their 'Arab Orthodoxy', ${ }^{26}$ given that the Melkite authors constituting the intellectual elite had received a Greek education that had equipped them to pursue quite prestigious professions. ${ }^{27}$ This group has been subdivided into two clearly-differentiated sectors: the Greek-speaking rüm and the mal(a)kiyyūn or suryāne that spoke Arabic and/or Syriac and shared with the rüm-among other things- the Byzantine liturgical corpus. ${ }^{28}$ These were therefore two distinct communities, which - despite their shared faith - represented two distinct human, cultural and linguistic situations; contact between the two weakened as the Arab/Syrian groups lost touch with the Byzantine world and grew remote from the events unfolding in the imperial capital, Constantinople. ${ }^{29}$

In 697, the structures of the Byzantine Empire started to be replaced by the Islamic model throughout the Islamic territories. The twofold process of Arabization and Islamization implemented through the policy introduced by the Umayyad authorities led to Arabic replacing Greek as the language of the administrative apparatus, although under the influence of the Hellenized Arab culture. ${ }^{30}$ This linguistic, political and cultural situation, together with the economic changes instituted in 697, heralded a new age in human relationships in the Near East. The completion in 691 of the Dome of the Rock on the Temple Mount in Jerusalem, and the circulation in 697 of coins proclaiming that God was One and Eternal and that Muhammad was

${ }^{24}$ Even in distant lands, see Fiey, "Rūm a l'Est de l'Euphrate".

${ }^{25}$ Nasrallah, "Syriens et Suriens", p. 496. Cf. Griffith, The Church in the Shadow of the Mosque, p. 139.

${ }^{26}$ Cf. Little, Peacemakers in Action, pp. 322-323.

${ }^{27}$ Hoyland, "Jacob of Edessa on Islam". Cf. Palmer, Monk and mason on the Tigris frontier, p. 166.

${ }_{28}$ Baumstark, Geschichte der syrischen Literatur, pp. 335-339. Cf. Crone and Cook, Hagarism, pp. 89-90. Cf. MacEvitt, The Crusades and the Christian World of the East, p. 8 .

${ }^{29}$ El Cheikh, Byzantium as Viewed by the Arabs, p. 119.

${ }^{30}$ Bowersock, Mosaics as History, p. 120. 
'the Messenger of God' (rasūl Allāh) not only replaced the habitual minting of bilingual coins in Greek and Arab as ordained by the various dawāwin, ${ }^{31}$ but also served to indicate that both culminations marked the dawn of a new era in which Islam presented itself as distinct from, and a rival - even a successor- to Christianity, the latter was forced onto the defensive not only in terms of lifestyle but also in religious and cultural terms. ${ }^{32}$

The labels used by the Christian Arab chroniclers to refer to Arabspeaking Christians draw a certain distinction between Melkites and pre-Islamic Arab-speaking Christians. For example, the Melkite Maḥbūb al-Manbijī (tenth century) refers to the latter as 'Christians from [amongst] the Arabs' (al-nașārā min al-'arab) ${ }^{33}$ and calls the native population of Palestine and Syria 'Arabs' who wrote in Greek ('āmmat al-'arab alladhīna kānū bi-l-Ša'm wa-Sūriyā kānat khutūtuhum bi-l-yūnāniyyah). ${ }^{34}$ The same writer, when recounting Chosroes' oppression of the inhabitants of Edessa, refers to them as "those who respected the criterion of the Melkites" ( $r a$ 'y al-mal(a)kiyyah), who were ordered to follow the precepts of the Jacobites (al-ya'qübiyyah). ${ }^{35}$ This information, transmitted by a Melkite, is valuable, because that native population probably comprised Aramaic-speaking Arabs (Aramaic was still in use well into the twelfth century $)^{36}$ who were the first to make use of the epithet malkāye, perhaps reflecting attempts at rapprochement aimed at uniting Chalcedonians with Monophysites under Justin II (565-578) between 566 and 571. In fact, Arab groups had peopled this vast area centuries before the advent of Islam. A whole range of Arab groups, for example, formed part of society in the kingdom of Hatrāa between the first and third centuries CE. We have evidence of "Arabs" in and around Edessa during the same period, and indeed some authors place Arab tribes at the founding of the city of Edessa, which was to be strongly Monophysite by the end of the fifth century CE. ${ }^{37}$ The same is true of the city of Palmyra and

31 Tsafrir, "Trade workshops and shops in Bet Shean/Scythopolis", pp. 78-82. See also Qedar, "Copper coinage of Syria", pp. 33-34.

${ }^{32}$ Hoyland, "Jacob of Edessa on Islam", p. 159. Cf. Bierman, Writing Signs, pp. 33-34.

33 Vasiliev, "Kitab al-'Unvan", vol. V, p. 457.

34 Vasiliev, "Kitab al-'Unvan", vol. V, p. 498.

35 Vasiliev, "Kitab al-'Unvan", vol. V, pp. 458-460.

${ }^{36}$ Segal, Edesa, 'the Blessed City', p. 238.

${ }^{37}$ Frend, "The Monks and the Survival of the East Roman Empire", p. 8. 
environs, due to a phenomenon common in parts of Syria and Mesopotamia at the end of Seleucid rule, where these shuy $\bar{u} k h$ Arabs remained independent of both the Roman and the Parthian Empires. These Arab groups were an integral part of a society in which Greek, Aramaic and Arabic were all freely spoken, in a Hellenizing setting ${ }^{38}$ which was later to bear fruit in the intellectual sphere, in the Syriac tradition among others. ${ }^{39}$ More important still, however, is the case of Syrian Bușrā, a highly-valuable geostrategic enclave in Late Antiquity ${ }^{40}$ which by the middle of the third century already had a Chris-

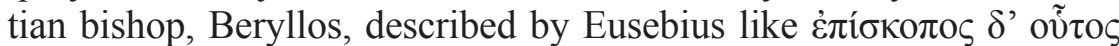

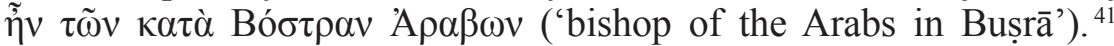
Over this whole area peopled by Arab tribes, Aramaic -in its dialectal variants- was the only language used in various types of writing ${ }^{42}$.

A truly remarkable blend of ethnic, cultural and linguistic elements were pooled and redefined under the influence of Christianity in the Near East; three major groups can be distinguished among the Christian population in the area: ${ }^{43}$

1. Greek groups of various ethnic origins whose culture was Greek.

2. Hellenized Syrian and Arab groups.

3. The largest group, comprising Aramaic- and Arab-speaking groups in Syria, Palestine and Mesopotamia.

Available data on the organization of Provincia Arabia ${ }^{44}$ indicate a clear distinction on economic or geographical grounds: the urban population comprised Hellenized Arabs and Syrians (group 2) living with pagan communities, ${ }^{45}$ whilst the rural population (fallähüna, the



${ }^{38}$ Drijvers and Healey, The Old Syriac Inscriptions, pp. 36-39.

${ }^{39}$ Baumstark, Geschichte der syrischen Literatur, p. 285. On this issue, see Watt, "Graeco Syriac Tradition".

${ }^{40}$ Bowersock, Roman Arabia, pp. 110-111.

${ }^{41}$ Eusebius, Historia ecclesiastica, VI,20.2, cf. 33.1, in Bardy (ed.), Eusèbe de Césarée. Cf. Millar, The Roman Near East, p. 400.

${ }_{42}$ Gorea, "Coupes magiques syriaques et manichéennes", p. 109.

43 Trimingham, Christianity Among the Arabs, pp. 212-213.

${ }^{44}$ Devreesse, "Le christianisme dans la Province d'Arabie"; Piccirillo, L'Arabia cristiana, pp. 191-217.

${ }^{45}$ Bowersock, Hellenism in Late Antiquity, pp. 35-39.

46 'Abbās, Ta'rīkh Bilād al-Sha'm, p. 96. 
Arabic and retained their traditional culture. Thus, the urban population included Greeks and Hellenized groups; both were Chalcedonians. By contrast, the rural population was eminently anti-Chalcedonian and therefore anti-Melkite.

In ideological terms, this division arose from fifth-century controversies regarding the nature of Christ. As a result, northern Arab Christians -both nomadic and sedentary- under Byzantine influence were Monophysites and thus under the authority of Edessa, the metropolis of the Syriac church within the Byzantine Empire, rather than Antioch, the metropolis of Greek Christendom, which the Syrian Aramaic communities considered remote; this accounts for the latter being mostly Monophysites. ${ }^{47}$ When addressing Egypt, the Melkites' Monothelite confession must also be borne in mind. ${ }^{48}$

\section{The Arabic cultural-linguistic program as an identitarian feature for the Melkite communities}

The policy of Arabization and Islamization instituted by the Umayyad caliphs like part of their legitimation ${ }^{49}$ prompted an unprecedented reaction among Christian authors writing in Greek, Syriac and Coptic. ${ }^{50}$ Nor were the Melkites slow to develop an intelligent cultural policy which may be regarded as complete, in that they succeeded in shaping a cultural project in Arabic based on original compositions and translated works, giving rise to what a leading scholar has termed 'the Christian Arab legacy' (al-turāth al-'arabi al-masi $h \bar{\imath}) .{ }^{51}$ At the same time, this project provided the Melkites with a twofold advantage: first, they were able to boast an Arab-language culture that was truly their own, as distinct from the Christian tradition in Greek, a linguistically-productive culture in the language used by the Christian Arabs; ${ }^{52}$ secondly, it afforded them an essential weapon -language- with which to fight an enemy who could be

${ }^{47}$ McCullough, A Short History of Syriac Christianity, pp. 78-85. Cf. al-Khūrī, "alMalkiyyūn", pp. 37-66 and 41-44.

${ }_{48}$ Nasrallah, Histoire du mouvement littéraire dans l'église melchite, vol. II/1, pp. 53-59.

49 Donner, "Umayyad Efforts at Legitimation".

${ }^{50}$ Fiey, "Umayyads in Syriac Sources".

${ }^{51}$ Samir, "Madkhal ilà al-turāth", pp. 35-49, 83-102 and 195-210. Cf. Samir, $A b \bar{u}$ Qurrah: al-Sìrah wa-l-maräji, fasc. I, p. 6.

52 Versteegh, The Arabic Language, p. 124. 
confronted only in Arabic, and clearly not in Greek, Syriac or Coptic. This distinctive feature is essential for understanding the sense of cultural, linguistic and ethnic identity of the Melkites as distinct from their Byzantine counterparts.

Implementation of this new project by the Umayyad conquerors evidently required the prior linguistic Arabization of an elite at least sufficient to start on the radical break with the previous Byzantine model. ${ }^{53}$ But the earliest surviving textual sample suggests that this process in fact affected the whole urban native population, from top to bottom. This is apparent in the fragment (vv. 20-31 and 51-61) of Psalm 78 (LXX: 77) from the Qubbat al-Khaznah of Damascus, laid out in double columns, Greek on the left and Arabic in Greek characters on the right; the fragment indicates that the celebration of the Eucharist in the Greek Orthodox faith, in the city of Damascus in the late seventh century, ${ }^{54}$ involved both a Greek-speaking and an Arabicspeaking group. ${ }^{55}$ Both were Christians, but the latter was not wholly a group Arabized as a result of the arrival of Islamic Arab troops; rather, it comprised Arabs belonging to tribes which had settled in Syria some centuries earlier. ${ }^{56}$ In this respect, it is interesting to note that Arabic appears to have been the only language spoken in the sixth century by Byzantium's foederati. This is indicated by the term

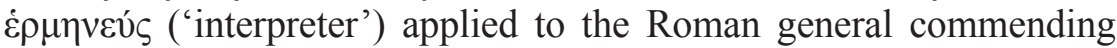
them -Andreas- suggesting that these Arab groups led by Byzantine generals only understood Arabic, even almost one hundred years after they first allied with the Byzantine army. However, this was probably not true of all groups or tribes; evidently, the Gassānid phylarchs ( $\varphi v$ $\lambda \alpha \rho \chi 0 \imath$ ) spoke some other language in addition to Arabic. ${ }^{57}$ It must thus be surmised that three linguistic communities coexisted: Greekspeakers, Arabic-speakers, and recently-Arabized groups with other mother tongues. The fact that the Qubbat al-Khaznah fragment used Greek rather than Arabic characters for the Arabic version shows how superficial the process of Arabization still was amongst the Greek

\footnotetext{
${ }^{53}$ For a consideration of this context, see Kennedy, "The Last Century of Byzantine Syria”.

${ }^{54}$ Violet, "Ein zweisprachiges Psalmfragment aus Damascus", pp. 429-430.

${ }_{55}^{5}$ Haddad, "La phonétique de l'arabe chrétien vers 700".

${ }^{56}$ For these tribes, see Nau, Les arabes chrétiens de Mésopotamie et de Syrie, pp. 31-94.

${ }^{57}$ Shahîd, Byzantium and the Arabs, vol. I.1, pp. 553-554. Cf. Aigrain, "Arabie", vol. III, p. 1190.
} 
clergy, who -like the monks- were to take some time to adopt Arabic as the language of cultural transmission. Thanks in some degree to contacts with the immigrant population in Syria, ${ }^{58}$ the Arabization of the Christian population was a progressive process that started in the latter years of the seventh century, when a linguistic form that Corriente described as "a birth certificate of Nabatî Arabic", the "forerunner' of Neo-Arabic" ${ }^{59}$ gained currency amongst the urban population. This -together with a by now wholly-Arabized ecclesiastical structure, ${ }^{60}$ accounts for the surviving corpus of anonymous translations made in the eight and ninth centuries in Syria and Palestine. ${ }^{61}$

Although not crucial to the linguistic aspect of Arabization, the role played in the pre-Islamic period by Arab groups acting as veritable 'tribal police' ${ }^{62}$ such as the Banū Lakhm ${ }^{63}$ among the Sassanian Persians, and the Byzantines' foederati, must have been important in the limes Orientalis. The same is true of the Banū Gassān, and of the North Arabian groups referred to by Syriac sources as 'arab $d$-rěhumiyē, i.e. 'Arabs of the Greeks', ${ }^{64}$ and even as tayyayye $d$-rěhuimiye ('Arabs of the Greeks') as against tayyāye d-parsāyē ('Arabs of the Persians'), the term used to describe the Banū Lakhm, ${ }^{65}$ even though the word tayyayye is used -along with other terms- to refer to the Muslims. ${ }^{66}$ Christian Arabic anthroponyms certainly feature strongly in pre-Islamic Greek inscriptions from Palaestina tertia, pointing to the existence of an Arab-speaking Christian group which would help to swell the ranks of the Melkites. This group, which lived in the northern Near East, central Mesopotamia, the West Bank, Transjordan and the Sinai Peninsula prior to the advent of Islam ${ }^{67}$

${ }^{58}$ Gaube, "Arabs in the Sixth Century Syria", p. 64. Cf. Crone, "Were the Qays and Yemen of the Umayyad period political parties?".

${ }^{59}$ Corriente, "The Psalter fragment from the Umayyad Mosque of Damascus", p. 319.

${ }^{60}$ Samir, "Michel évêque melkite de Damas".

${ }^{61}$ Graf, Die christlich-arabische Literatur, pp. 8-24.

${ }^{62}$ See Donner, The early Islamic conquests, pp. 43-44, 292 and pp. 45-47, 293 for Ghassānids and Lakhmids respectively.

${ }^{63}$ Rothstein, Die Dynastie der Lakhmiden in al-Hira.

${ }^{64}$ Shahîd, "Ghassanid and Umayyad structures"; Wright (ed. and transl.), The Chronicle of Joshua, p. 39.

${ }^{65}$ Smith (ed.), Extracts from the Ecclessiastical History, p. 20, cf. 101.

${ }^{66}$ Cf. the expression tayyāye d-Mhmt ('the Arabs of Muhamad), Motzki, The Biography of Muhammad, p. 278.

${ }_{67}$ Peters, "The Arabs on the Frontier". Cf. Mayerson, "The Desert of Southern Palestine", pp. 167-169. See also Devreesse, "Le Christianisme dans la péninsule sinaïtique". 
represented the settlement of a variety of Arabic within a non-Arabicspeaking territory; it subsequently went through the usual stages of pidginization and creolization to attain dialectal scope, ${ }^{68}$ as indicated by linguistic phenomena in Christian Arab texts. The early works written in, or translated into, Arabic by Christian Arab authors, are relatively simple in terms of grammar and lexis -as might be expected from any contact language- and generally contain a mixture of two languages. That linguistic mixture gave rise to a hybridization involving languages that were vehicles for different cultures; this in turn prompted a cultural fusion in the new group, eventually leading to depidginization and decreolization, and hence to a reconvergence towards a standard register of the original language of the group. One example of this sort of Christian Arab in that milieu, dated in 14 April

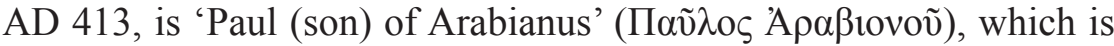
clearly the Greek equivalent of the Arabic Bawlus b. al-'Arab ('Paul, son of the Arab'), ${ }^{69}$ and he was certainly not an isolated case. ${ }^{70}$ Thus, the process of Arabization taking place amongst Christian communities -enhanced by the Arab substrate provided by Arab tribes and/or Christian Arab groups ${ }^{71}$ - had a marked impact over the eighth century, although progressive Arabization did not wholly eliminate Greek language and culture, which in the eighth century were still to be found in the monasteria of Palestine, though surrounded by swift Arabization. ${ }^{72}$ The cultivation of this Greek literature was the work of an ecclesiastical elite, and more particularly of a pro-Chalcedonian sector -a leading figure being John of Damascus (d. ca. 749)whose authors would continue to use Greek up until the end of the eighth century. ${ }^{73}$

This new ethnic-linguistic and confessional situation, prompted by the presence of the Melkites, acquired renewed vigour through the

${ }^{68}$ Versteegh, Pidginization and creolization.

${ }^{69}$ Meimaris and Kritikakou-Nikolaropoulou, Inscriptions from Palaestina Tertia, $\mathrm{p}$. 197, no. 103, lines 1-2. References to the (pagan) Arabs are also usual in the Nabataean inscriptions, see Cook, A glossary of the Aramaic inscriptions, p. 94.

${ }^{70}$ Knauf, "Umm el-Jimāl", pp. 580-586.

${ }^{71}$ Vööbus, History of Ascetism in the Syrian Orient. Cf. Sauget, "La littérature arabe chrétienne ancienne", p. 151.

${ }^{72}$ Blake, "La littérature grecque en Palestine", pp. 376-378. Cf. Vailhé, "Le monastère de Saint-Sabas", p. 21-28, also for decadence pp. 168-177; Vailhé, "Les écrivains de Mar-Saba".

${ }^{73}$ Griffith, "John of Damascus and the Church". 
cultural undertaking on which they had embarked; so much so, that -in their hands-Arabic was to become, in textual terms, a true lingua franca amongst Christian Arabs, and the Melkites were to be its leading advocates and exponents. ${ }^{74}$ Given that the Melkites were Chalcedonians, Greek might be expected to be their langue supérieure or their langue de prestige, whilst in sociological terms Arabic would be relegated to a secondary position. This, however, did not happen; Arabic fairly rapidly displaced Greek - though not totally, as we have seen - while Greek continued to be used despite the policy introduced by the Islamic state with the twofold aim of boosting Arabization and reducing the use of Greek.

Amongst Melkite authors, the declining use of Greek was offset by the intrinsic Hellenization both of the writers (e.g. Michel the Synkellus) $)^{75}$ and of the work they produced, in the form of either original compositions or translations; on more than one occasion, indeed, Greek (as well as Coptic and Syriac) survived within Arabic texts through calques or mere transliterations. ${ }^{76}$ In this respect, the Melkites were responsible for merging two linguistic and cultural entities into a single language. Greek - a language doomed to vanish from public life - was to be ideologically grafted onto Arabic, which was to become the new language of administration and public life for a given area, if not for the whole of the Near East and beyond. This Hellenistic element within Chalcedonian Christian Arab groups, and the faith shared with their counterparts in Constantinople, were strengthened by the policy of Arabization and Islamization introduced by the Umayyad authorities. The Islamic authorities themselves, for their part, were also affected in various ways by the strength of this Hellenistic cultural interaction, ${ }^{77}$ which exerted its effects both directly, through the Byzantine link, but also indirectly through its influence on Semitic groups in earlier periods, a wholly natural influence forming part of the general process of Hellenistic acculturation that had been taking place on Semitic soil since centuries earlier. ${ }^{78}$

${ }_{74}$ Blau, "A Melkite Arabic literary lingua franca".

${ }^{75}$ Peristeris, "Literary and Scribal Activities", p. 174.

76 Monferrer Sala, "Notas lexicográficas", p. $79 \S 3.1,84 \S 3.22$.

${ }^{77}$ Fowden and Fowden, Studies on Hellenism, p. 128. Cf. Fowden, Qusayr 'Amra, pp. 266-267. Cf. Bowersock, Mosaics as History, p. 120.

${ }_{78}$ Millar, The Roman Near East, pp. 397-399. 
There is no doubt at all that Melkite textual production started in the second half of the eighth century, and continued to grow thereafter. The earliest known text is a work called $F \bar{l}$ tathlith Allāh alwăhid, produced in around $738 \mathrm{CE}$. At about this time, church authors embarked upon the systematic production of texts, an undertaking led by the renowned Melkite Theodore Abū Qurrah (ca. 750-ca. 825), an admirer of John of Damascus. ${ }^{79}$ It is this author -leaving aside certain flaws in the manuscripts in various languages attributed to him- that best embodies the distinctive features of the Melkite element: an Arab-speaking Chalcedonian with a Greek cultural background, although he apparently never wrote in Greek, Abū Qurrah was readily conversant with the Christian Palestinian Aramaic script and with the language itself, ${ }^{80}$ a Christian dialectal variety of Western Aramaic ${ }^{81}$ containing Arabisms resulting from contact with Arab-speaking groups, that were already to be found in Old Syriac. ${ }^{82}$ This cultural and linguistic hybridization characteristic of the Christian Near East at the time is undoubtedly the hallmark feature of the Melkite element. It is interesting to note that a kind of historical chiasmus, of a linguistic/ideological nature, took place between John of Damascus and Theodore Abū Qurrah, marking two distinct stages: whilst John never wrote in Arabic, and his work was always bound by the horizons of Constantinople intellectualism, ${ }^{83} \mathrm{Abu}$ Qurrah never wrote in Greek, and his work always displayed the influence of the Iraqi mutakallimūn.

In view of the foregoing, it might be assumed that this was a dichotomous process in which Greek was supplanted by Arabic and the Greek Orthodox tradition was replaced by the rationalism of the mutakallimūn; yet this would be a mere reductio ad absurdum, since -as indicated earlier- Hellenistic elements in various cases persisted through Arabic elements. This is far from being a process of substitution, in which Melkite intellectuals simply renounced their Greek

${ }^{79}$ On this writer, see Griffith, Theodore Abū Qurrah, and Samir, Abū Qurrah. Vida, bibliografia y obras.

${ }^{80}$ Desremaux, "The Birth of a New Aramaic Script".

${ }^{81}$ For a summary of this dialect, see Beyer, The Aramaic Language, pp. 51-53.

${ }^{82}$ Müller-Kessler, Grammatik des Christlich-Palästinisch-Aramäischen, p. $7 \S$ 1.1.6.2; Healey, "Lexical Loans in Early Syriac".

${ }^{83}$ For the reception of John of Damascus' work in Arabic, see Atiya, "St. John Damascene". 
background. Quite the opposite: Melkite intellectuals, as heirs to, and representatives of, a specifically Christian historic, ethnic and linguistic situation, zealously defended the two elements defining them, their distinctive ethnic and linguistic features, grouped under a single label 'Arabic'. But at the same time as being Arabs, they also sought to defend their Graeco-Arabic, Syriac-Arab (or Copto-Arabic, as the case may be) culture through the manifestation of their Christian faith. This was not, therefore, a process of change with respect to their Greek Orthodox fellow-believers, but rather a reaffirmation of their historical status, a kind of Melkite shu'übiyyah through which Melkite intellectuals distinguished themselves both from the Greek Orthodox groups and from the Muslims. At the same time, this defense of their identity as a people (shu'übiyyah) also served as a means of reasserting the Arabic origin of the communities occupied by Muslim armies, an authentic yet distinct Arabhood ('urübah), a Christian Arabhood whose roots could be traced back beyond Islam into the period of the Jahhiliyyah. ${ }^{84}$

Sozomen's account of the encounter between the Arabs and the Christian priests and monks in the mid-fifth century CE has to some extent coloured the explanation of the origin of Christian Arab literature. Whilst the surviving Christian Arab texts undoubtedly originated at the Palestinian monasteria, ${ }^{85}$ it should be noted that many of the texts produced at the monasteries of St. Catherine, St. Sabas or St. Charitōn were translations, recensions or adaptations of works mainly in Greek or Syriac, which constituted the twin linguistic and cultural pillars of the Melkite community. Can we therefore safely ignore these two key elements when searching for the origin of Christian Arabic literature? Probably not, as Griffith indirectly suggested some years ago when describing the linguistic (and by extension cultural) situation in the Palestinian monasteries; his account focuses on the linguistic interaction between Greek, Christian Palestinian Aramaic, 'Melkite Arabic' and -to a lesser extent- Armenian and Georgian in the heart of an Orthodox oikouméne..$^{86}$ Indeed, the Christian Arab texts betray the influence of living Aramaic, visible in the Neo-Arabic layer of the 'Melkite Arabic' texts. ${ }^{87}$ Moreover, as indi-

${ }^{84}$ Al-Ṭabarī, Annales, vol. I, p. 834.

${ }^{85}$ Griffith, "The monks of Palestine", pp. 13-28.

${ }^{86}$ Griffith, "From Aramaic to Arabic".

${ }^{87}$ Blau, "The Influence of Living Aramaic", pp. 141-142. 
cated earlier, the translations made at the Byzantine monasteries were produced by a cosmopolitan monastic elite working in the great South Palestininan lavrce, whose linguistic skills cannot have extended either to monastery life in general nor to all monasteries, ${ }^{88}$ even though most monks probably used Arabic as their colloquial language and a second language for liturgical purposes. This is natural enough, since the lavrce had become centers for the conservation and generation of Melkite culture, following the decline of Syria in the late sixth century $\mathrm{CE}$ and the Islamic occupation, which led to many churches being abandoned for economic and social reasons. ${ }^{89}$

It is interesting to see how Arabic-speaking Melkite theologians exercised their intellectual leadership from the South Palestinian lavrce from the eighth century onwards, although this undertaking was not restricted to the monasteries; this is evident in the pastoral and literary achievements of Abū Qurrah, bishop of the Melkite community at Harrān, and of the authors working outside monastic centers. Abū Qurrah, the leading Melkite author, also displayed a feature peculiar to Christian Arab writers (both Chalcedonian and anti-Chalcedonian): the strong influence of Iraqi mutakallimūn practice on key intellectual activities. ${ }^{90}$ The Melkite authors modeled their debating technique on that of these Muslim intellectuals, coupled with exegetical and hermeneutical tools inherited from the Christian tradition; all this was combined with the influence of the Hellenistic culture shared by the Chalcedonians. The result achieved its maximum expression in a series of philosophical and religious debates (majāis) prompted by Christian-Muslim encounters between the seventh and thirteenth centuries. ${ }^{91}$

While the influence of the mutakallimūn model undoubtedly shaped the lexis used by the Melkite authors, which clearly drew on the Qur'ān, on a number of technical theological terms, and on the debating techniques employed by Muslim authors, it is also important to remember that this Islamic originality was often no more than an

${ }^{88}$ Samir, "La tradition arabe chrétienne", p. 53.

${ }^{89}$ Kennedy, "The Melkite Church". See also the wealth of information provided by Schick, The Christian Communities of Palestine. On the status of Christian communities in Syria and Mesopotamia, see Ferré, "Chrétiens de Syrie et de Mésopotamie"; cf. Dennet, Conversion and Poll Tax in Early Islam.

${ }^{90}$ On this issue see Griffith, "The Syriac letters of Patriarch Timothy I".

${ }^{91}$ On this genre, see Griffith, "The Monk in the Emir's Majlis". 
adaptation of procedures characteristic of the Christian exegesis that influenced Islamic theology in its formative stages. ${ }^{92}$ It was natural enough that Arab-speaking Chalcedonian authors should draw on a linguistic model like the Qur'àn: not only because within the framework of Arabization they had no other option, but also because they needed a linguistic archetype on which to (re)construct a reality appropriate to their legacy, the product of a linguistic and cultural journey that had started out from two languages - Greek and Syriac - which had subsequently become archaeological emblems of Arab Christianity, and which the Chalcedonian authors were themselves replacing by Arabic. In that sense, the Melkites found themselves in a position similar to that of Jewish authors, who abandoned Aramaic in favor of Judaeo-Arabic, taking the linguistic model provided by the Qur'ān as the basis for a deeper understanding of their sacred language, Hebrew. ${ }^{93}$

This aspect deserves to be stressed, since the role played by Melkite authors and translators in the dissemination of Greek thought, in Arabic, amongst Muslim intellectuals was crucial to the Muslim reception of the Greek cultural heritage. ${ }^{94}$ But that influence was exerted through translations into Arabic, a good example being the 'translations-adaptations' of Aristotle's works by Theodore Abū Qurrah. As a result, the Greek heritage acquired new vigour, and was to some extent revitalized through the native languages of the Melkites, Arabic and Syriac. Syriac, indeed, came to embody the paradigmatic lingua sacra, a Christian antidote to the Islamic doctrine of the inherent superiority of the Arabic language ${ }^{95}$ as the language used by God to reveal the Qur'ān to his messenger Muhammad. After all, even though Greek was the most widely-used literary and liturgical language amongst the Melkites at the time of the invasion by Arab troops, the sector of the Chalcedonian community that originally accepted the ecclesiastical policy of the Byzantine Basileús Heraclius spoke Syriac,

${ }^{92}$ Cook, "The Origins of Kalām". Cf. Monferrer Sala, "Apologética racionalista".

${ }^{93}$ On the Judaeo-Arabic register, see Blau, The Emergence and Linguistic Background of Judaeo-Arabic. Cf. the interesting information aduced in Yěhûdāh b. Quraysh's Risālah, see van Bekkum, "The 'Risāla' of Yehuda Ibn Quraysh". The critical edition of the Risālah was done by Becker, The Risāla of Judah Ben Quraysh.

${ }^{94}$ For the case of philosophy, see Parry, "Byzantine and Melkite Iconophiles",

p. 46. Cf. Griffith, “Answers for the Shaykh", p. 280.

${ }_{95}$ Wilde, "Lingua sacra?", p. 76. 
whilst their people in Egypt spoke one of the dialectal varieties of Coptic. ${ }^{96}$ This fits perfectly with data indicating that Arab acculturation was first evident amongst the Palestinian Melkites, followed by the Jacobites, the Nestorians and - somewhat later - the Copts.

When the son of Abū Sufyān, Mu'āwiyah (ca. 602-680), was proclaimed first caliph of the Umayyad dynasty in Jerusalem in 661, and set up his residence in Damascus, the Syrian population was largely Christian, and many families belonging to the ruling classes opted to emigrate to lands controlled by the Byzantine Empire. ${ }^{97}$ Amongst those that remained there were Arab groups; Mu'āwiyah himself married a Christian Jacobite from the Banū Kalb, Maysūn, a marriage which brought him useful alliances with various Christian Arab tribes in North Arabia, ${ }^{98}$ whereas other privileged groups such as some members of the Banū Gassān are known to have emigrated to the Byzantine Empire. ${ }^{99}$ But the Jacobites were not the only groups to collaborate with the caliph, the Melkites, too, played a major role in the policy of collaboration instituted by Mu'āwiyah. A good example is that of Sarjūn b. Manșūr al-Nașrān̄i, 'Serge, son of Manșūr the Christian', the father of John of Damascus (Yūhannā b. Manșūr b. Sarjūn), who before entering the monastery of Mār Sābā worked in caliph 'Abd al-Malik's administration in Damascus at a difficult time for the Melkite church, which had no Chalcedonian patriarch in Jersualem. ${ }^{100}$ Sarjūn succeeded his father Manșūr, who had worked for Mu'āwiyah, and was appointed head of the 'Syrian Treasury' (Dīwān al-Sha'm). ${ }^{101}$ The interesting genealogical information provided by the nasab appears to suggest a degree of acculturation; in any case, it clearly indicates that both father and son must have been fluent in Arabic, since the father must have held a senior financial post whilst the son was de facto the head of finance for the nascent Umayyad caliphate. ${ }^{102}$

${ }^{96}$ Brock, "A Syriac Fragment on the Sixth Council"; Micheau, "Eastern Christianities", pp. 373-403 and 399.

${ }^{97}$ Haldon, "“Citizens of Ancient Lineage...'?

98 Aigrain, "Arabie", vol. III, pp. 1310-1311.

99 Shahîd, "Sigillography in the service of history".

${ }^{100}$ On John of Damascus, see Nasrallah, Saint Jean de Damas.

${ }^{101}$ Chabot (ed. and transl.), Chronique de Michel le Syrien, vol. II, p. 477. Cf. Niebuhr (ed.), Theophanis Chronographia, vol. I, p. 559, and Sahas, John of Damascus on Islam, p. 26, and n. 5.

102 Aigrain, "Arabie", vol. III, pp. 1311-2; cf. Sahas, John of Damascus on Islam, pp. 26-30.

Al-Qantara XXXIII 2, 2012, pp. 445-471 ISSN 0211-3589 doi:10.3989/alqantara.2011.017 
These are by no means isolated cases. There is evidence that Mu'āwiyah appointed one Habīb, an Arab described as a "wicked Syrian", to lead one of the two divisions of his army. ${ }^{103}$ Another Habīb appears on the scene later, in the reign of caliph 'Abd al-Malik, when appointed Bishop of Edessa by the metropolitan James of Edessa. In this city, for instance, the influence of the Christian community on Mu'āwiyah was quite effective, since the caliph ordered the church destroyed by the earthquake of $678 \mathrm{CE}$ to be reconstructed because of the Christians' zealous efforts according to the narration given by Theophanes:

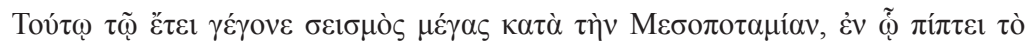

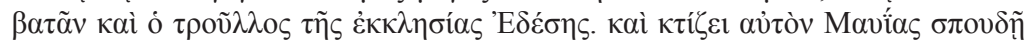

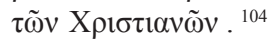

In this year there was a big earthquake in Mesopotamia, in which the pulpit and the dome of the church of Edessa fell, and Mu'āwiyah restored it because of the Christians' zealous efforts.

On the other hand, accounts concerning these two aforementioned figures of Habīb and James of Edessa are of interest, in that the monks' demand for the restoration of Greek language training testifies to the degree of Arabization in local monastic communities, in which the use and knowledge of Greek had disappeared. ${ }^{105}$ It was during this period, in the reign of 'Abd al-Malik, that several figures of considerable intellectual importance emerged amongst the Arab groups, including the celebrated bishop George of the Arabs and bishop Joseph of the Banū Tagilib, also known as Joseph of the Tayyaye, i.e. of the Arabs. ${ }^{106}$ The Melkites, therefore, were clearly in the vanguard of that 'Nabați Arabic' (al-lughah al-'arabiyyah alnabatiyyah) that had been consolidated -in linguistic and cultural terms- far away from the Arabian Peninsula.

At the same time, the decline of Greek as a written language in Syria and Palestine during the Arab conquest -and indeed in Egyptreflected something more than just the Christians' preference for their respective liturgical languages in the two territories -i.e. Aramaic

${ }^{103}$ Chabot (ed. and transl.), Chronique de Michel le Syrien, vol. II, p. 441.

${ }^{104}$ Niebuhr (ed.), Theophanis Chronographia, vol. I, p. 544. Cf. Chabot (ed. and transl.), Chronique de Michel le Syrien, vol. II, p. 457.

${ }^{105}$ Chabot (ed. and transl.), Chronique de Michel le Syrien, vol. II, p. 472.

${ }^{106}$ Chabot (ed. and transl.), Chronique de Michel le Syrien, vol. II, p. 475b; cf. 476b. 
dialects in Syria and Palestine, and Coptic dialects in Egypt. Nor was it only a further consequence of the replacement of Greek by Arabic in the territories of Dār al-Isläm. ${ }^{107}$ The Melkite identity was shaped by something more than the sum of the liturgical elements in their respective native languages and the process of linguistic and cultural Arabization, although both certainly played their part. But a third, equally-important, element was the strong and outspoken ethnic and cultural sentiment of Arab-speaking Christians in Islamic territory. Each of these elements made its own contribution to the forging of a Melkite identity whose distinctive feature was a sense of ethnic, cultural and linguistic Arabhood.

In the reign of the upright caliph 'Uthmān b. 'Affān (644-656), with Muea awiyah commanding the armies at the Syrian-Palestinian borders, Michel the Syrian recounts in his 'Chronicle' that "the patriarch called the bishops and summoned the Tanūkayē, the 'Aqūlayē and the Tūeaye, who knew the Arabic and Syriac languages, and charged them to translate the Gospel into Arabic". ${ }^{108}$ This summons arose from an order given to the patriarch by Emir 'Amr ( $A m r \bar{u}$ bar Sa'd, amīr Tayyayē) who, after subjecting him to some searching questions, issued the following instructions: "Translate for me your Gospel into the language of the Saracens, that is of the Tayyayē". ${ }^{109}$ It was this that prompted the alleged debate between the Orthodox Syriac patriarch John III and the governor of the jund of Homs 'Umayr b. Sa'd, who - according to tradition - held a session (majlis) in May $644 \mathrm{CE} .{ }^{110}$ The three Arab tribes mentioned in the text are none other than the famous Arab tribes converted to Christianity by the Jacobite metropolitan 'Ahudemme in the mid-sixth century: the Banū Tanūh, the Banū 'Aqūl and the Banū Țayyi'. ${ }^{111}$

To judge from the foregoing, the Arab-speaking Christian tribes clearly provided considerable support at this early stage, with a striking number of converts to Christianity in the area of Syria in the fifth century. ${ }^{112}$ Moreover, the text to which we have just referred

${ }^{107}$ Micheau, "Eastern Christianities", p. 390.

${ }^{108}$ Chabot (ed. and transl.), Chronique de Michel le Syrien, vol. II, p. 432b. Cf. Chabot, (ed. and transl.), Chronicon Anonymum, I, pp. 205-206 §§ 128-129.

${ }_{109}$ Chabot (ed. and transl.), Chronique de Michel le Syrien, vol. II, p. 431b-432b.

110 Samir, "Qui est l'interlocuteur musulman du patriarche syrien?".

111 Nau, "Histoires d'Ahoudemmeh et de Marouta", p. 28-29.

112 Nau, Les arabes chrétiens de Mésopotamie et de Syrie, pp. 38-39. 
suggests that, just as these Christian tribes came under the authority of the Orthodox Syrian patriarchs, other Arab-speaking Christian tribes came under that of the Greek patriarchs, with whom they shared both their faith and a certain Hellenistic influence, though each had their own language and culture - orthodox Greeks and Melkite Arabs.

\section{Bibliography}

'Abbās, I., Ta'rīkh Bilād al-Sha'm fì l-'așr al-umawī 41-132 H./661-750 CE, Amman, al Jāmi'ah al-Urdunniyah, 1999, $2^{\text {nd }}$ ed.

Aigrain, R., "Arabie", in Baudrillart, A. (dir.), Dictionnaire d'histoire et de géographie ecclésiastiques, Paris, Letouzey et Ané, 1924, vol. III, pp. 11581339.

Atiya, A. S., "St. John Damascene: Survey of the Unpublished Arabic Versions of his Works in Sinai", in Arabic and Islamic Studies in Honor of Hamilton A.R. Gibb, Leiden, Brill, 1965, pp. 73-83.

Atiya, A. S., A History of Eastern Christianity, London, Methven, 1968.

Bardy, G. (ed.), Eusèbe de Césarée. Histoire ecclésiastique, Paris, Editions du Cerf, 1952, 1955 and 1958, 3 vols.

Baumstark, A., Geschichte der syrischen Literatur mit Ausschluß der christlichpalästinensischen Texte, Bonn, A Weber, 1922 (reed. Berlin, 1968).

Becker, D., The Risāla of Judah Ben Quraysh, Tel-Aviv, Tel-Aviv University, 1984.

Beyer, K., The Aramaic Language: Its Distribution and Subdivisions, transl. from the German by J. F. Healey, Göttingen, Vandenhoeck, 1986.

Bierman, I. A., Writing Signs: The Fatimid Public Text, Berkeley-Los Angeles, University of California Press, 1998.

Blake, R., "La littérature grecque en Palestine au VIIIe siècle", Le Muséon, 78 (1965), pp. 367-80.

Blau, Joshua, The Emergence and Linguistic Background of Judaeo-Arabic. A Study of the Origins of Middle Arabic, Jerusalem, Ben Zui Institute, 1981.

Blau, Joshua, "The Influence of Living Aramaic on Ancient South Palestinian Christian Arabic", in Sokoloff, M. (ed.), Arameans, Aramaic and the Aramaic Literary Tradition, Ramat-Gan, Bar-Ilan University Press, 1983, pp.

141-142.

Blau, Joshua, "A Melkite Arabic literary lingua franca from the second half of the first millennium", BSOAS, 57 (1994), pp. 14-16.

Bowersock, G. W, Roman Arabia, Cambridge, Mass., Harvard University Press, 1983. 
Bowersock, G. W., Hellenism in Late Antiquity, Ann Arbor, MI, University of Michigan Press, 1993.

Bowersock, G. W., Mosaics as History. The Near East from Late Antiquity to Islam, Cambridge, Mass.-London, The Belknap Press of Harvard University, 2006.

Brock, S. P., "A Syriac Fragment on the Sixth Council”, Oriens Christianus, 57 (1973), pp. 63-71.

Chabot, J.-B. (ed. and transl.), Chronicon Anonymum ad A.D. 819; Chronicon Anonymum ad annum Christi 1234 pertinens, Leuven, Imprimerie Orientaliste L. Durbecq, 1937.

Chabot, J.-B. (ed. and transl.), Chronique de Michel le Syrien, patriarche jacobite d'Antioche (1166-1199), Paris, Ernest Leroux, 1899, 1901 and 1905, 4 vol.

Cook, M. A., "The Origins of Kalām”, BSOAS, 43 (1980), pp. 32-43.

Cook, S. A., A glossary of the Aramaic inscriptions, Cambridge, Cambridge University Press, 1898.

Corriente, F., "The Psalter fragment from the Umayyad Mosque of Damascus: A birth certificate of Nabatī Arabic", in Monferrer-Sala, J.P. (ed.), Eastern Crossroads: Essays on Medieval Christian Legacy, Piscataway, NJ, Gorgias Press, 2007, pp. 303-332.

Crone, P. and Cook, M., Hagarism, The making of the Islamic World, Cambridge, Cambridge University Press, 1977.

Crone, P., "Were the Qays and Yemen of the Umayyad period political parties?", Der Islam, 71 (1994), pp. 44-49.

Dennet, D. C. Jr., Conversion and Poll Tax in Early Islam, Cambridge, Mass., Harvard University Press, 1950 (rep. Delhi, 2000).

Desremaux, A., "The Birth of a New Aramaic Script in Bilad al-Sham at the End of the Byzantine Period", in Bakhit, M. A. and Schick, R. (ed.), Proceedings of the Third Symposium on Bilad al-Sham, 24-29 October 1987, Amman, University of Jordan, 1989, vol. II, pp. 26-36.

Devreesse, R., "Le Christianisme dans la péninsule sinaïtique dès origines à l'arrivée des Musulmans, Revue biblique, 49 (1940), pp. 205-223.

Devreesse, R., "Le christianisme dans la Province d'Arabie", Revue Biblique, 50-52 (1941-1944), pp. 110-146.

Dick, I., Melkites: Greek Orthodox and Greek Catholics of the Patriarchates of Antioch, Alexandria and Jerusalem, Boston, Sophia Press, 2004.

Donner, F. M., The early Islamic conquests, Princeton, NJ, Princeton University Press, 1981.

Donner, F. M., "Umayyad Efforts at Legitimation: The Silent Heritage of the Umayyads", in Borrut, R. and Cobb, P. M. (ed.), Héritages Omeyyades/ Umayyad Legacies, Leiden, Brill, 2010, pp. 187-211. 
Drijvers, H. J. W. and Healey, J. F., The Old Syriac Inscriptions of Edessa \& Osrhoene. Texts, Translations and Commentary, Leiden-Boston-Köln, Brill, 1999.

El Cheikh, N. M., Byzantium as Viewed by the Arabs, Cambridge, Mass, Harvard University Press, 2004.

Every, G., "Syrian Christians in Palestine in the Early Middle Ages", The Eastern Churches Quarterly, 7 (1946), pp. 363-372.

Ferré, A., "Chrétiens de Syrie et de Mésopotamie aux deux premiers siècles de l'islam", Islamochristiana, 14 (1988), pp. 71-106.

Fiey, J. M., 'Rūm a l'Est de l'Euphrate”, Le Muséon, 90, 3-4 (1977), pp. 365-420.

Fiey, J. M., "Umayyads in Syriac Sources", in Bakhit, M. A. and Schick, R. (ed.), Proceedings of the Third Symposium on Bilad al-Sham, 24-29 October 1987, Amman, University of Jordan, 1989, vol. II, pp. 11-25.

Fortescue, A., The Eastern Churches Trilogy. I. The Orthodox Eastern Church, London, Catholic Trust Society, 1929.

Fortescue, A., The Eastern Churches Trilogy. II. The Lesser Easternn Churches, London, Catholic Trust Society, 1913.

Fowden, G. and Fowden, E. K., Studies on Hellenism, Christianity and the Umayyads, Athens, National Hellenic Research Foundation, 2004.

Fowden, G., Qușayr 'Amra: Art and the Umayyad Elite in Late Antique Syria, Berkeley, Ca, University of California Press, 2004.

Frend, W. H. C., "The Monks and the Survival of the East Roman Empire in the Fifth Century", Past and Present, 54 (1972), pp. 3-24.

Gaube, H., "Arabs in the Sixth Century Syria: Some Archaeological Observations", in Proceedings of the First International Conference on Bilad alSham, 20-25 April 1974, Yarmuk, Yarmuk University, 1984, pp. 61-65.

Gorea, M., "Coupes magiques syriaques et manichéennes en provenance de Mésopotamie", in Briquel-Chatonet, F., Débie, M. and Desremaux, A. (ed.), Les inscriptions syriaques, Paris, Geuthner, 2004.

Graf, G., Die christlich-arabische Literatur bis zur fränkischen Zeit (Ende des 11. Jahrhunderts). Eine literarhistorische Skizze, Freiburg im Breisgau, Herder, 1905.

Graf, G., Verzeichnis arabischer kirchlicher Termini, Leuven, Imprimerie Orientaliste L. Durbecq, 1954.

Griffith, S. H., "Eutychius of Alexandria on the Emperor Theophilus and Iconoclasm in Byzantium: A Tenth Century Moment in Christian Apologetics in Arabic", Byzantion, 52 (1982), pp. 154-190.

Griffith, S. H., "The monks of Palestine and the growth of Christian literature in Arabic", The Muslim World, 78 (1988), pp. 1-28.

Griffith, S. H., Theodore Abū Qurrah: The Intellectual Profile of an Arab Christian Writer of the First Abbasid Century, Tel Aviv, Tel Aviv University, 1992.

Al-Qanțara XXXIII 2, 2012, pp. 445-471 ISSN 0211-3589 doi:10.3989/alqantara.2011.017 
Griffith, S. H., "From Aramaic to Arabic: The Languages of the Monasteries of Palestine in the Byzantine and Early Islamic Periods", Dumbarton Oaks Papers, 51 (1997), pp. 11-31.

Griffith, S. H., "The Monk in the Emir's Majlis: Reflections on a Popular Genre of Christian Literary Apologetics in Arabic in the Early Islamic Period", in Lazarus-Yafeh, Hava (ed.), The Majlis: Interreligious Encounters in Medieval Islam, Wiesbaden, Otto Harrassowitz, 1999, pp. 13-65.

Griffith, S. H., "Apologetics and Historiography in the Annals of Eutychios of Alexandria: Christian Self-Definition in the World of Islam", in Ebied, R. and Teule, H. (ed.), Studies on the Christian Arabic Heritage in honour of Father Prof. Samir Khalil Samir at the occasion of his sixty-fifth birthday, Louvain, Peeters, 2004, pp. 65-89.

Griffith, S. H., “Answers for the Shaykh: A 'Melkite' Arabic text from Sinai and the Doctrines of the Trinity and the Incarnation in 'Arab Orthodox' Apologetics", in Grypeou, E. et al. (ed.), The Encounter of Eastern Christianity with Early Islam, Leiden-Boston, Brill, 2006, pp. 277-309.

Griffith, S. H., "The Syriac letters of Patriarch Timothy I and the Birth of Christian Kalām in the Mu tazilite Milieu of Baghdad and Bașrah in Early islamic Times", in van Bekkum, W.J. et al. (ed.), Syriac Polemics: Studies in Honour of Gerritt Jan Reinink, Leuven-Paris-Dudley, Peeters, 2007, pp. 103-132.

Griffith, S. H., The Church in the Shadow of the Mosque: Christians and Muslims in the World of Islam, Princeton-Oxford, Princeton University Press, 2008.

Griffith, S. H., "John of Damascus and the Church in Syria in the Umayyad Era: The Intellectual and Cultural Milieu of Orthodox Christians in the World of Islam", Hugoye 11, 2 (2008), pp. 207-237, [on line], available at http://syrcom.cua.edu/Hugoye/Vol11No2/HV11N2Griffith.html [viewed 20/08/2012].

Griffith, S. H., “' 'Melkites', 'Jacobites', and the Christological Controversies in Arabic in Third/Ninth Century Syria", in Thomas, D. (ed.), Syrian Christians under Islam: The First Thousand Years, Leiden, Brill, 2011.

Gutas, D., Greek Thought, Arabic Culture: The Graeco-Arabic Translation Movement in Baghdad and Early 'Abbasid Society $\left(2^{\text {nd }}-4^{\text {th }} / 8^{\text {th }}-10^{\text {th }}\right.$ Centuries $)$, London-New York, Routledge, 1998.

Haddad, R., "La phonétique de l'arabe chrétien vers 700", in Canivet, P. and Rey-Coquais, J.-P. (ed.), La Syrie de Byzance a l'Islam, VII'-VIIIE siècles, Damas, Adrien Maisonneuve, 1992, pp. 159-164.

Haldon, J. F., “ 'Citizens of Ancient Lineage...'? The Role and Significance of Syrians in the Byzantine Élite in the Seventh and Eighth Centuries", in van Bekkum, W. J. et al. (ed.), Syriac Polemics: Studies in Honour of Gerritt Jan Reinink, Leuven-Paris-Dudley, Peeters, 2007, pp. 91-102.

Harrak, A. (transl.), Chronicle of Zuqnīn. Parts III and IV, A.D. 488-775, Toronto, Pontifical Institute of Mediaeval Studies, 1999. 
Healey, J. F., "Lexical Loans in Early Syriac: a Comparison with Nabataean Aramaic", Studi Epigrafici e Linguistici, 12 (1995), pp. 75-84.

Hitti, Ph. K., History of Syria, including Lebanon and Palestine, New York, The Macmillan Company, 1951, 2 vol. (reed. Piscataway, NJ, 2004, 2nd ed.).

Howard-Johnston, J., Witnesses to a World Crisis: Historians and Histories of the Middle East in the Seventh Century, Oxford, Oxford University Press, 2010.

Hoyland, R. H., "Jacob of Edessa on Islam”, in Reinink, G. J. and Klugkist, A. C. (ed.), After Bardaisan. Studies on Continuity and Change in Syriac Christianity in Honour of Professor Han J.W. Drijvers, Louvain, Peeters, 1999, pp. 149-160.

Kennedy, H. "The Melkite Church from the Islamic Conquest to the Crusades: Continuity and Adaptation in the Byzantine Legacy", in The $17^{\text {th }}$ International Byzantine Congress: The Major Papers, New Rochelle, NY, Caratzas, 1986, pp. 325-343.

Kennedy, H. N., "The Last Century of Byzantine Syria: A reinterpretation", in Kennedy, H. N., The Byzantine and Early Islamic Near East, Aldershot, Ashgate, 2006, pp. 141-83.

Knauf, E. A., "Umm el-Jimāl: An Arab Town in Late Antiquity", Revue Biblique, 91 (1984), pp. 578-86.

Kraemer, J. L., Humanism in the Renaissance of Islam: the Cultural Revival during the Buyid Age, Leiden, Brill, 1986.

Al-Khūrī, I., "al-Malkiyyūn: bațriyarkiyyatu-hum al-anțākiyyah wa-lughatuhum al-wațaniyyah wa-l-taqsiyyah", Al-Mashriq, 34 (1936), pp. 37-66.

Little, D., Peacemakers in Action: Profiles of Religion in Conflict Resolution, Cambridge, Cambridge University Press, 2007.

MacEvitt, C., The Crusades and the Christian World of the East: Rough Tolerance, Philadelphia, University of Pennsylvania Press, 2008.

Al-Mas'ūdī, Kitāb al-tanbīh wa-l-ishrāf, de Goeje, M. J. (ed.), Leiden, Brill, 1894.

Mayerson, P., "The Desert of Southern Palestine According to Byzantine Sources", Proceedings of the American Philosophical Society, 107, 2 (1963), pp. 160-72.

McCullough, W. St., A Short History of Syriac Christianity to the Rise of Islam, Chico, Calif., Scholars Press, 1982.

Meimaris, Y. and Kritikakou-Nikolaropoulou, K.I., Inscriptions from Palaestina Tertia. Vol. Ia: The Greek Inscriptions from Ghor es-Safi (Byzantine Zoora), Athens, National Hellenic Research Foundation, 2005.

Michael the Syrian, Chronique, Chabot, J.-B. (ed. and transl.), Paris, Ernest Leroux 1899, 1901, 1905, 3 vol. 
Micheau, F. "Eastern Christianities (eleventh to fourteenth century): Copts, Melkites, Nestorians and Jacobites", in Angold, M. (ed.), Eastern Christianity, Cambridge, Cambridge university Press, 2006, pp. 373-403.

Millar, F., The Roman Near East, 31 BC-AD 337, Cambridge, Mass.-London, Harvard University Press, 1993.

Monferrer Sala, J. P., “"Apologética racionalista» de Abū Qurrah en el Maymar fì wuğūd al-Hāliq wa-l-dīn al-qawìm II/2,12-14”, Anales del Seminario de Historia de la Filosofía, 22 (2005), pp. 41-56.

Monferrer Sala, J. P., "Notas lexicográficas sobre textos árabes extraislámicos", Estudios de Dialectología Norteafricana y Andalusí, 9 (2005), pp. 73-92.

Motzki, H., The Biography of Muhammad: the issue of the sources, LeidenBoston, Brill, 2000.

Müller-Kessler, C., Grammatik des Christlich-Palästinisch-Aramäischen. I. Schriftlehre, Lautlehre, Formenlehre, Hildesheim-Zürich-New York, Georg Olms, 1991.

Nasrallah, J., Saint Jean de Damas. Son époque, sa vie, son cuvre, Harissa, Saint Paul, 1950.

Nasrallah, J., "Syriens et Suriens", in Symposium Syriacum 1972 (célebré dans les jours 26-31 octobre 1972 à l'Institut Pontifical Oriental de Rome), Rome, Pontificium Institutum Orientalium Studiorum, 1974, pp. 487-503.

Nasrallah, J., Histoire du mouvement littéraire dans l'église melchite du Ve au $X X^{e}$ siècle, Damas, Institut Français de Damas, 1996.

Nau, F., "Histoires d'Ahoudemmeh et de Marouta, suivies du Traité d'Ahoudemmeh sur l'homme", in Graffin, R. and Nau, F. (ed.), Patrologia Orientalis III, Paris, Firmin-Didot et Cie, 1909, pp. 5-51.

Nau, F., Les arabes chrétiens de Mésopotamie et de Syrie du VII e au VIII ${ }^{e}$ siècle, Paris, Imprimerie Nationale, 1933.

Niebuhr, B. G. (ed.), Theophanis Chronographia, Bonn, Weber, 1839, 1841, Corpus Scriptorum Historiae Byzantinae, 2 vol.

Palmer, A., Monk and mason on the Tigris frontier: The early history of Tur 'Abdin, Cambridge, Cambridge University Press, 1990.

Palmer, A., The Seventh-Century in the West-Syrian Chronicles, Liverpool, Liverpool University Press, 1993, with the collaboration of S. Brock and R. Hoyland.

Parry, K., "Byzantine and Melkite Iconophiles under Iconoclasm", in Dendrino, Ch. et al. (ed.), Porphyrogenita: Essays on the History and Literature of Byzantium and the Latin East in Honour of Julian Chrysostomides, Aldershot, Ashgate, 2003, pp. 137-151.

Peristeris, A., "Literary and Scribal Activities at the Monastery of St. Sabas", in Patrich, J. (ed.), The Sabaite Heritage in the Orthodox Church from the Fifth Century to the Present, Leuven, Peeters, 2001, pp. 171-194. 
Peters, F. E., "The Arabs on the Frontier of Syria before Islam", in Proceedings of the First International Conference on Bilad al-Sham, 20-25 April 1974, Yarmuk, Yarmuk University, 1984, pp. 141-173.

Piccirillo, M., L'Arabia cristiana. Dalla provincia imperiale al primo periodo islamico, Milano, Jaca Book, 2002.

Qedar, S., "Copper coinage of Syria in the seventh and eighth century A.D.", Israel Numismatic Journal, 10 (1988-89), pp. 27-39.

Renaudot, E., Historia Patriarcharum Alexandrinorum Jacobitarum A.D. marco usque ad finem saeculi XIII, Paris, Franciscum Fournier, 1713.

Rothstein, G., Die Dynastie der Lakhmiden in al-Hira, Ein Versuch zur arabisch-persischen Geschichte zur Zeit der Sasaniden, Hildesheim, Georg Olms, 1968 (reed.).

Sahas, D. J., John of Damascus on Islam: The "Heresy of the Ishmaelites", Leiden, Brill, 1972.

Samir, Samir Khalil, "La tradition arabe chrétienne. État de la question, problèmes et besoins", in Samir, Samir Khalil (ed.), Actes du premier congrès international d'études arabes chrétiennes (Goslar, septembre 1980), Rome, Pontificium Institutum Studiorum Orientalium, 1982, pp. 21-120.

Samir, Samir Khali1, "Madkhal ilà al-turāth al-'arabī al-masīḥ̄ al-qadīm”, Ṣadīq al-Kähin, 23 (1983), pp. 35-49, 83-102, 195-210.

Samir, Samir Khalil, "Qui est l'interlocuteur musulman du patriarche syrien Jean III (631-648)?, in Drijvers, H. J. W. et al. (ed.), IV Symposium Syriacum 1984: Literary Genres in Syriac Literature (Gröningen - Oosterhesselen 10-12 September), Rome, Pontificium Institutum Studiorum Orientalium, 1987, pp. 387-400.

Samir, Samir Khalil, "Michel évêque melkite de Damas au $9^{e}$ siècle. A propos de Bišr Ibn al-Sirrı̄”, Orientalia Christiana Periodica, 53, 2 (1987), pp. 439-441.

Samir, Samir Khalil, Abū Qurrah: al-Sìrah wa-l-marājì, Beirut, Dār al-Mashriq, 2000, 2 fasc.

Samir, Samir Khalil, Abū Qurrah. Vida, bibliografía y obras, Monferrer-Sala, J. P. (transl.), Córdoba, Servicio de Publicaciones de la Universidad de Córdoba, 2005.

Sauget, J.-M., "La littérature arabe chrétienne ancienne", in Sauget, J.-M., Littératures et manuscrits des chrétiens syriaques et arabes. Recueil d'articles publié par L. Duval-Arnould et F. Rilliet, Vatican City, Biblioteca Apostólica Vaticana, 1998, pp. 147-174.

Schick, R., The Christian Communities of Palestine from Byzantine to Islamic Rule: A Historical and Archaeological Study, Princeton, NJ, The Darwin Press, 1995.

Segal, J. B., Edesa, 'the Blessed City', London, Oxford University Press, 1970. Severus b. al-Muqaffa', Historia patriarcharum alexandrinorum, Seybold, C. F. (ed.), Leuven, Secrétariat du Corpussco, 1910, 1962, 2 vol. 
Shahîd, I., "Ghassanid and Umayyad structures: A case of Byzance après Byzance", Canivet, P. and Rey-Coquais, J.-P. (ed.), La Syrie de Byzance à l'Islam, VII ${ }^{-}$VIII ${ }^{e}$ siècles, Damas, Institut Français de Damas, 1992, pp. 299-307.

Shahîd, I., Byzantium and the Arabs in the Sixth Century, Washington DC, Dumbarton Oaks, 1995, 2 vol.

Shahîd, I., "Sigillography in the service of history: new light", in Sode, C. and Takakcs, S. (ed.), Novum Millennium. Studies dedicated to Paul Speck, Aldershot, Ashgate, 2001, pp. 369-378.

Smith, J.P. (ed.), Extracts from the Ecclessiastical History of John Bishop of Ephesus, Leiden, Brill, 1909.

Swanson, M. N., The Coptic Papacy in Islamic Egypt (641-1517), Cairo-New York, The American University in Cairo Press, 2010.

Al-Ṭabarī, Annales, De Goeje, M. J. (ed.), Leiden, Brill, 1898.

Thomason, Sarah G., Language contact: an introduction, Edinburgh-Washington, Edinburg University Press-Georgtown University Press, 2001.

Trimingham, J. Spencer, Christianity Among the Arabs in Pre-Islamic Times, Beirut, Librairie du Liban, 1979.

Tsafrir, Y., "Trade workshops and shops in Bet Shean/Scythopolis, $4^{\text {th }}-8^{\text {th }}$ centuries", in Mango, M. M. (ed.), Byzantine Trade, $4^{\text {th }}-12^{\text {th }}$ centuries, Franham, Surrey, Ashgate, 2009, pp. 61-82.

Vailhé, S., "Les écrivains de Mar-Saba”, Echos d'Orient, 2 (1898-99), pp. 33-47.

Vailhé, S., "Le monastère de Saint-Sabas", Echos d'Orient, 3 (1899-1900), pp. 18-28, pp. 168-77.

Van Bekkum, W. J., "The 'Risāla' of Yehuda Ibn Quraysh and its Place in Hebrew Linguistics", in Koerner, K. et al. (ed.), The History of Linguistics in the Near East, Amsterdam-Philadelphia, John Benjamins, 1983, pp. 71-91.

Vasiliev, A., "Kitab al-'Unvan", in Graffin, R. and Nau, F. (ed.), Patrologia Orientalis III, Paris, Firmin-Didot et Cie, 1910.

Versteegh, K., Pidginization and creolization: the case of Arabic, Amsterdam, John Benjamins, 1988.

Versteegh, K., The Arabic Language, New York, Columbia University, 1997.

Violet, B., "Ein zweisprachiges Psalmfragment aus Damascus", Orientalistische Litteratur-Zeitung, 4 (1901), pp. 384-403, 425-488

Vööbus, A., History of Ascetism in the Syrian Orient: A Contribution to the History of Culture in the Near East. II. Early Monasticism in Mesopotamia and Syria, Leuven, Secrétariat du Corpussco, 1959, 1960, 2 vol.

Wallace-Hadrill, D. S., Christian Antioch: A study of early Christian thought in the East, Cambridge, Cambridge University Press, 1982.

Watt , J. W., "Graeco Syriac Tradition and Arabic Philosophy in Bar Hebraeus", in Teule, H. et al. (ed.), The Syriac Renaissance, Leuven-Paris-Walpole, Ma, Peeters, 2010, pp. 123-133. 
Wellhausen, J., Das arabische Reich und seine Sturz, Berlin, G. Reimer, 1902. Wilde, C., "Lingua sacra? Some reflections on Christian discussions of fadā'il al-suryāniyya and i'jāz al-Qur'ān', in Monferrer-Sala, J. P. (ed.), Eastern Crossroads: Essays on Medieval Christian Legacy, Piscataway, NJ, Gorgias Press, 2007, pp. 61-82.

Wilfong, T. G., "The non-Muslim communities: Christian communities", in Petry, C. F. (ed.), The Cambridge History of Egypt. I: Islamic Egypt, 6401517, Cambridge, UK, Cambridge University Press, 1998, pp. 175-197.

Wright, W. (ed. and transl.), Chronicle of Joshua the Stylite, composed in Syriac A.D. 507, London, Cambridge University Press, 1882.

Recibido: 15/11/2011

Aceptado: 04/06/2012 